("Whitman's 'Overstaid Fraction' Again," Walt Whitman Review 20 [June 1974], 67). The crisis of Section 38, it should be noted, is a crisis of the mind; it thus parallels the earlier major crisis in the poem, which is of the body: the "Touch" crisis of Sections 27-29 (lines 611-647), in which the poet also loses control of himself, although for obviously different reasons.

3 See, for example, James E. Miller, Jr., A Critical Guide to Leaves of Grass (Chicago: University of Chicago Press, 1957), 24: "Here [at the end of Section 37] the poet reaches the nadir of degradation, particularly in the emotion of shame."

4 Joel Jay Belsen, “Whitman's 'Overstaid Fraction," Walt Whitman Review 17 (June 1971), 64; Kahn, 71.

5 James E. Miller, Jr., A Critical Guide, 25.

6 Kahn, 71.

7 Stephen A. Black, Whitman's fourneys into Chaos: A Psychoanalytic Study of the Poetic Process (Princeton: Princeton University Press, 1975), 96.

8 Selected Essays (New York: Harcourt, Brace \& World, Inc., 1960), 7-8.

9 Notebooks and Unpublished Prose Manuscripts, ed. Edward F. Grier (New York: New York University Press, 1984), 1:63. For a shrewdly perceptive contemporary treatment of the dual nature of the artist, see Jorge Luis Borges, "Borges and I," in Labyrinths: Selected Stories and Other Writings (New York: New Directions, 1964), 246-247.

10 In a helpful and perceptive reading of "Song of Myself," Howard J. Waskow has written, "The 'usual mistake' is to stay too long in the poetic night - to assume that the self is so healthy and whole that it can exchange identities endlessly, without injuring itself or the process." (Whitman: Explorations in Form [Chicago and London: The University of Chicago Press, 1966], 180.)

11 This is the clear and obvious meaning. Joel Jay Belsen's definition (Belsen, 65) of "fraction" as "the rite of breaking the bread in the celebration of the Eucharist" is far too strained a reading to merit consideration. As Sholom J. Kahn comments (73), "To wrench the 'fraction' out of context and import the Eucharist here is not to read Whitman, but to write one's own poem. ... The test of a proper critical reading must be the poetic text as a whole."

12 Edwin Haviland Miller's comment on this passage is particularly helpful: "When he [the poet] resumes the 'overstaid fraction' he is ready to 'troop forth replenished with supreme power, one of an average unending procession': he has been preoccupied with pain, which excludes or minimizes joy; he has been preoccupied with defeat, which excludes victory; tragedy, or 'my own crucifixion,' has absorbed him in the separateness of pain and self-pity and has momentarily eclipsed the comic vision of men united in joy" (Walt Whitman's Poetry: A Psychological fourney [New York: New York University Press, 1968], 106).

\title{
WHITMAN AND VAN GOGH: AN EXCHANGE
}

In her essay "Van Gogh's 'Starry Night' and Whitman: A Study in Source" (WWQR, 3 [Summer 1985], 1-15), Jean Schwind stresses the influence that Whitman's poetry, especially From Noon to Starry Night, must have had on the creation of Van Gogh's "Starry Night" of June 1889. In the second half of the article Schwind points to the painting "Wheatfield with Cypress" (National Gallery, London [F 615]), which she calls its "daylight counterpart." From this juxtaposition she develops a comparison between these two paintings and Whitman's poems "Prayer of Colum- 
bus" and "Passage to India," Columbus's voyage from east to west being reflected, she says, by the shifting from right to left, or "westward," of the cypress that forms the dominant element in both paintings.

Schwind bases her theory that these pictures were "counterparts" on a letter in which Van Gogh wrote to his brother about a coming exhibition, mentioning two pictures that might be shown together there:

Shortly after "Starry Night" was completed, Paul Gauguin was appointed to organize an art exhibit for the 1890 World's Fair. Hoping to be included in the show, Van Gogh wrote to Theo about mounting "Starry Night" for display. Although Van Gogh's painting was finally excluded from the exhibit, his instructions regarding "Starry Night" are nonetheless important. "Starry Night," Van Gogh told Theo, must hang with its daylight counterpart, his "Wheatfield with Cypress." (p. 7)

One might consider it a minor detail that the exhibition meant in letter 593 was not one to be organized by Gauguin for 1890, but the regular exhibition of the Indépendents in 1889. It is important, however, to have a closer look at the text of the letter. Van Gogh did not write that the night scene must hang with his "Wheatfield with Cypress"; he did not mention a title, but wrote: "le paysage aux verdures jaunes qui était dans le cadre en noyer." In the translation of the New York Graphic Society edition of the Complete Letters, the sentence reads: "So as not to be indifferent, and not to exhibit anything too mad, perhaps the 'Starry Night' and the landscape with yellow vegetation, which was in the walnut frame" (3:178). There can be no doubt that what was meant here was one of his garden or park scenes, done in Arles in the fall of 1888. When he had to leave Arles for Saint-Rémy and was sending Theo the pictures he had done so far (see my The Complete Van Gogh [1980], p. 388), he wrote him: "I am working on an avenue of chestnut trees with pink blossoms," adding: "This will make a pendant to the garden which is in the walnut frame" (letter 589). This garden or park scene must have been one of Van Gogh's favorite pictures and was therefore given the distinction of being put in the walnut frame that he had had made in October (see letters 547 and 548). It most probably was "A Lane in a Public Garden" (F 472), but certainly not "Wheatfield with Cypress."

What is even more serious is that in the text of the letter quoted above, the title "the Starry Night" ("la nuit étoilée") does not refer to the picture discussed in the article. The "Starry Night" of the Museum of Modern Art (F 612) was painted in the second half of June 1889, a few weeks after letter 593 was written. Van Gogh was talking about an earlier picture of a nightscene, painted in Arles in September 1888, and showing a view of the Rhône under a star-filled sky (F 474). This picture, therefore, has as little to do with Whitman's possible influence on Van Gogh's "Starry Night" of 1889 as has his "Wheatfield with Cypress."

Victoria, British Columbia

JAN HULSKER

\section{fean Schwind replies:}

I am grateful for Jan Hulsker's comments, and certainly bow to his superior scholarship on Van Gogh. A major difficulty in being a student of the "sister arts" is that my formal training in and knowledge of literature are a good deal stronger than my expertise in art history. When a specialist like Mr. Hulsker speaks, I listen with respect. 
I am not, however, entirely convinced by his objections to my argument. The identity of the painting that Van Gogh calls "la nuit étoilée" in letter 593 is less certain than Mr. Hulsker makes it appear. Several of my sources, including Sven Lovgren's excellent Genesis of Modernism, contend that the painting referred to in this letter to Theo is the Museum of Modern Art's "Starry Night." Likewise, the identity of the painting Van Gogh describes (without naming by title) as the pendant for "Starry Night" is open to question, as Mr. Hulsker implicitly admits in saying that this painting is "most probably" "A Lane in a Public Garden." Van Gogh was working on both "Starry Night" and "Wheatfield with Cypress" in the summer of 1889, and "Wheatfield" offers such telling contrasts to "Starry Night" that it seemed to me most clearly the "landscape with yellow vegetation" that Van Gogh intended as a companionpiece to "Starry Night." 